OPEN ACCESS

Edited by:

Åke Sjöholm,

Gävle Hospital, Sweden

Reviewed by:

Antonio Brunetti,

Università degli studi Magna Græcia

di Catanzaro, Italy

Michaela Tencerova,

University of Southern Denmark

Odense, Denmark

*Correspondence:

Larissa A. Shimoda

Ishimod1@jhmi.edu

Specialty section:

This article was submitted

to Diabetes,

a section of the journal

Frontiers in Endocrinology

Received: 24 February 2018

Accepted: 11 May 2018

Published: 29 May 2018

Citation:

Polak J, Punjabi NM and Shimoda LA

(2018) Blockade of Endothelin-1

Receptor Type B Ameliorates

Glucose Intolerance and Insulin

Resistance in a Mouse Model of

Obstructive Sleep Apnea.

Front. Endocrinol. 9:280.

doi: 10.3389/fendo.2018.00280

\section{Blockade of Endothelin-1 Receptor Type B Ameliorates Glucose Intolerance and Insulin Resistance in a Mouse Model of Obstructive Sleep Apnea}

\author{
Jan Polak ${ }^{1,2}$, Naresh M. Punjabi ${ }^{1}$ and Larissa A. Shimoda ${ }^{1 *}$ \\ ${ }^{1}$ Division of Pulmonary and Critical Care Medicine, Johns Hopkins University, Baltimore, MD, United States, ${ }^{2}$ Department for \\ the Study of Obesity and Diabetes, Third Faculty of Medicine, Charles University, Prague, Czechia
}

Obstructive sleep apnea (OSA) is associated with insulin resistance (IR) and glucose intolerance. Elevated endothelin-1 (ET-1) levels have been observed in OSA patients and in mice exposed to intermittent hypoxia $(I H)$. We examined whether pharmacological blockade of type $A$ and type $B E T-1$ receptors $\left(E T_{A}\right.$ and $\left.E T_{B}\right)$ would ameliorate glucose intolerance and $\mathrm{IR}$ in mice exposed to $\mathrm{H}$. Subcutaneously implanted pumps delivered

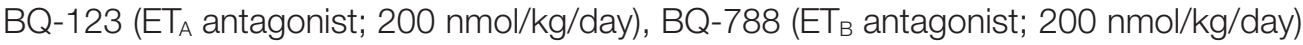
or vehicle (saline or propyleneglycol [PG]) for 14 days in C57BL6/J mice (10/group). During treatment, mice were exposed to $\mathrm{IH}$ (decreasing the $\mathrm{FiO}_{2}$ from $20.9 \%$ to $6 \%, 60 / \mathrm{h}$ ) or intermittent air (IA). After $I H$ or IA exposure, insulin $(0.5 \mathrm{IU} / \mathrm{kg})$ or glucose $(1 \mathrm{mg} / \mathrm{kg})$ was injected intraperitoneally and plasma glucose determined after injection and area under glucose curve (AUC) was calculated. Fourteen-day $\mathrm{IH}$ increased fasting glucose levels (122 \pm 7 vs. $157 \pm 8$ mg/dL, PG: $118 \pm 6$ vs. $139 \pm 8$; both $p<0.05)$ and impaired glucose tolerance (AUC glucose: $_{19,249 \pm 1105}$ vs. 29,124 $\pm 1444, P G$ AUC glucose: $18,066 \pm 947$ vs. $25,135 \pm 797$; both $p<0.05)$ in vehicle-treated animals. $1 \mathrm{H}$-induced impairments in glucose tolerance were partially ameliorated with $\mathrm{BQ}-788$ treatment (AUC glucose: $21,969 \pm 662 ; p<0.05)$. Fourteen-day $\mathrm{H}$ also induced $I R\left(A \cup C_{\text {glucose: }}\right.$ : $7185 \pm 401$ vs. $8699 \pm 401 ; p<0.05)$. Treatment with BQ-788 decreased IR under IA (AUC glucose: $5281 \pm 401, p<0.05)$ and reduced worsening of IR with $\mathrm{IH}\left(\mathrm{AUC} \mathrm{C}_{\text {glucose: }}\right.$ : $7302 \pm 401, p<0.05)$. There was no effect of BQ-123 on $\mathbb{H}$-induced impairments in glucose tolerance or IR. Our results suggest that ET-1 plays a role in $\mathrm{IH}$-induced impairments in glucose homeostasis.

\footnotetext{
Keywords: obstructive sleep apnea, endothelin, endothelin receptor, bosentan, diabetes
}

\section{INTRODUCTION}

Obstructive sleep apnea (OSA) is a common condition characterized by repeated episodes of complete or partial upper airway collapse during sleep, resulting in repetitive drops in hemoglobin oxygen saturation and sleep fragmentation. Affecting about $5-15 \%$ of the general population $(1,2)$, OSA represents a considerable health burden, increasing the risk of hypertension $(3,4)$, cardiovascular 
disease (5-8) and all-cause mortality (9-11) independently of other traditional risk factors. Furthermore, research in the past decade suggests a role for OSA in the pathogenesis of insulin resistance (IR), glucose intolerance, metabolic syndrome and type 2 diabetes independent of age, obesity or fat distribution (12-14).

Although mechanisms linking OSA with impaired glucose homeostasis are not fully understood, several lines of evidence suggest that intermittent hypoxia (IH) plays a key role in inducing metabolic impairments. Experimental evidence from animal models suggests that both acute and prolonged exposure to $\mathrm{IH}$ worsened multiple aspects of glucose homeostasis including fasting glycemia, whole-body glucose tolerance and insulin sensitivity, muscle glucose uptake, hepatic glucose output, pancreatic $\beta$-cell function, viability and insulin secretion (15-21). Furthermore, impaired insulin sensitivity and pancreatic dysfunction were observed in healthy human volunteers acutely exposed to $\mathrm{IH}$ (22). It has been suggested previously that modulation of autonomic activity, altered corticotropic function, increased oxidative stress, activation of inflammatory pathways or higher circulating adipokines might represent the intermediate molecular and endocrine mechanisms imposing the metabolic toll of intermittent hypoxemia $(23,24)$. More recently, elevated levels of a circulating hormone, endothelin-1 (ET-1), and increased expression of cellular ET-1 receptors were demonstrated after IH exposure in vitro and in patients with OSA (25-31). Elevated ET-1 levels play a key role in abnormal carotid body functioning, leading to augmented sympathetic activation and development of systemic hypertension found in OSA $(32,33)$, while continuous positive airway pressure therapy effectively lowered blood pressure as well as ET-1 levels (27).

Substantial evidence suggests a potential link between ET-1 and the pathogenesis of metabolic impairments associated with type 2 diabetes. For example, ET-1 levels are elevated in patients with type 2 diabetes and metabolic syndrome $(34,35)$ as well as in animal models of diabetes $(36,37)$. Furthermore, ET-1 can directly interfere with cellular insulin signaling (38-42), enhance hepatic glucose output (43), diminish glucose uptake (40, 44-47), impair insulin secretion (48) and stimulate lipolysis in adipose tissue $(39,49)$ - effects directly contributing to hyperglycemia and development of type 2 diabetes. A causal role for ET-1 is further corroborated by studies documenting improved glucose homeostasis and insulin sensitivity after ET-1 receptor blockade in insulin-resistant rodents, healthy volunteers and insulinresistant subjects $(47,50-52)$.

Collectively, these findings indicate that chronically elevated ET-1 levels could play a fundamental role in the development of IR and glucose intolerance; however, it remains unclear whether ET-1 is involved in the development of metabolic impairments associated with IH and OSA and whether pharmacological treatment with ET-1 receptor antagonists would provide metabolic benefit in these subjects. In this study, we employed a mouse model of OSA to investigate whether selective pharmacological blockade of ET-1 type $\mathrm{A}\left(\mathrm{ET}_{\mathrm{A}}\right)$ or type $\mathrm{B}\left(\mathrm{ET}_{\mathrm{B}}\right)$ receptors would ameliorate $\mathrm{IH}$-induced alterations in glucose metabolism such as whole-body glucose tolerance, insulin sensitivity and insulin secretion.

\section{MATERIALS AND METHODS}

All procedures involving animals were approved by the Johns Hopkins University Animal Care and Use Committee and followed NIH principles of laboratory animal care.

\section{Selective ET-1 Receptor Antagonist Treatment}

Adult male C57BL6/J mice (Jackson Labs, age 6-8 weeks) were used for this study. All drugs and vehicles were administered via osmotic minipumps (Model 1002, Alzet, Cupertino, CA, USA) implanted subcutaneously in the dorsal region under isoflurane anesthesia (1-2\% isoflurane in oxygen, Baxter, Deerfield, IL, USA) and incisions closed with 2-3 sutures. Pumps were filled with $100 \mu \mathrm{l}$ of: (a) BQ-123 (0.407 mg/mL dissolved in saline; American Peptide, Sunnyvale, CA, USA), a selective $\mathrm{ET}_{\mathrm{A}}$ antagonist; (b) BQ-788 $(0.509 \mathrm{mg} / \mathrm{mL}$ dissolved in propylene glycol; American Peptide, Sunnyvale, CA, USA), a selective $\mathrm{ET}_{\mathrm{B}}$ antagonist; (c) saline (vehicle for BQ-123) or (d) propylene glycol (vehicle for BQ-788; SigmaAldrich, St. Louis, MO, USA). The osmotic minipumps delivered a constant flow-rate of $0.25 \mu \mathrm{l} / \mathrm{h}$, resulting in a dose of $200 \mathrm{nmol} /$ $\mathrm{kg}$ /day of BQ-123 or BQ-788 in each animal ( $25 \mathrm{~g}$ body weight).

\section{Protocol for IH}

All animals were allowed a recovery period of $24 \mathrm{~h}$ after surgery before subsequent exposures. Mice were housed in custommodified cages connected with plastic tubing to a gas control delivery system regulating the flow of nitrogen, oxygen and compressed air into cages as previously described $(19,53)$. IH was induced by programmable solenoid valves and flow regulators, which were used to alter the composition of the gas within the cages so that during each cycle of hypoxia, the inspired fraction of oxygen $\left(\mathrm{FiO}_{2}\right)$ was reduced from $21 \%$ to $6-7 \%$ over a period of $30 \mathrm{~s}$ and rapidly returned to $21 \%$ during the following $30 \mathrm{~s}$. For the control exposure (intermittent air [IA]), animals were exposed to alternating periods of air $\left(\mathrm{FiO}_{2}=21 \%\right)$ simulating a pattern of air flow at intervals identical to intermittent hypoxic exposure. On average, 60 episodes of oxygen desaturation were induced per hour mimicking oxyhemoglobin desaturations observed in severe OSA (53). All animals were housed at room temperature and subjected to a $12 \mathrm{~h}$ light/dark cycle. Exposures to $\mathrm{IH}$ and control exposures were conducted for $12 \mathrm{~h}$ during the dark phase of the light cycle. At the end of exposures, plasma samples were obtained or metabolic functions were assessed, as described below. Blood pressure was measured in acclimatized and trained animals (three exposures to the measuring routine on separate days before recordings were performed) using the non-invasive tail-cuff technique (CODA system, Kent Scientific, Torrington, CT, USA). Because IH can induce some weight loss, food intake was recorded and adjusted daily such that the body weight of groups followed the same trajectory. Animals were sacrificed by isoflurane overdose on the last day of the exposures.

\section{Intraperitoneal Glucose Tolerance Test (GTT) and Insulin Tolerance Test (ITT)}

An intraperitoneal GTT was performed after a $5 \mathrm{~h}$ fast $(n=10$ for each group). Following a glucose injection $(1 \mathrm{~g} / \mathrm{kg}$ glucose 
dissolved in saline), glucose levels were measured at 0, 10, 20, 30, 60, 90 and 120 min after the glucose injection from tail-snip blood samples using a glucometer (Accu-Check Aviva, Roche, Indianapolis, IN, USA). An ITT ( $n=10$ per group) was similarly performed after a $2 \mathrm{~h}$ fast by measuring blood glucose levels at $0,10,20,30,40,50,60,90$ and $120 \mathrm{~min}$ after injecting $0.5 \mathrm{IU} / \mathrm{kg}$ of insulin (Humulin R, $100 \mathrm{U} / \mathrm{mL}$, Eli Lilly, Indianapolis, IN, USA). The GTT and ITT measurements were performed in a distinct set of freely moving animals with continued $\mathrm{IH}$ or control exposures. Glucose-induced insulin secretion $(n=10$ per group) was assessed by measuring insulin levels using the Mouse Ultrasensitive EIA kit (Alpco, Salem, NH, USA) in plasma separated from blood obtained by cardiac puncture (after quick isoflurane anesthesia) $30 \mathrm{~min}$ after a $1 \mathrm{~g} / \mathrm{kg}$ glucose injection. Fasting insulin levels were evaluated in separate group of animals. Blood was collected in tubes containing heparin $(5 \mu \mathrm{L}$ heparin/ $1 \mathrm{~mL}$ blood), centrifuged at $2000 \mathrm{~g}$ for $10 \mathrm{~min}$ to separate plasma from circulating blood cells, plasma transferred to a clean tube and samples frozen immediately and kept at $-80^{\circ} \mathrm{C}$ until analysis. The homeostasis model assessment (HOMA) was used to derive HOMA- $\beta$ ([20-Insulin]/ [Glucose-3.5]) as a measure of $\beta$-cell function (54). Plasma ET-1 levels were measured in identical plasma samples as fasting insulin levels using the Endothelin-1 Quantikine ELISA Kit (R\&D Systems Inc., Minneapolis, MN, USA).

\section{Statistical Analysis}

Data are reported as mean and standard error of the mean (SEM). The effect of ET-1 receptor blockade was assessed by comparing the GTT- and ITT-derived parameters between the IH (drug- and vehicle-treated conditions) and their respective control exposure groups. Differences between groups in ITT and GTT glucose profiles were examined using ANOVA with repeated measures while between-group differences in all other variables were tested using two-way ANOVA with exposure group (IH versus control exposure) and treatment group (antagonist versus vehicle) as the between-subjects factors. Area under glucose curve (AUC) during the ITT was calculated using the trapezoidal rule using the entire testing period of $120 \mathrm{~min}$. Body weight was used as a covariate in ANOVA. All tests were performed in SPSS for
Windows 13.0 (SPSS Inc., Chicago, IL, USA). A $p$ value $<0.05$ was considered statistically significant.

\section{RESULTS}

\section{Cardiovascular Parameters}

In saline-treated animals, exposure to $\mathrm{IH}$ increased both systolic and diastolic systemic blood pressure (Table 1). Additionally, IH exposure increased heart rate in the saline-treated group (557 \pm 6 vs. $654 \pm 77$ beats/min, $p<0.05)$. In animals under control exposures (IA), none of the treatments (BQ-123, propylene glycol or BQ-788) had a significant effect on blood pressure or heart rate, but in all three groups, the $\mathrm{IH}$-induced increase in blood pressure was prevented (ANOVA, $p<0.05$ ). The IH-induced increase in heart rate was not ameliorated by BQ-123 treatment $(599 \pm 21$ vs. $682 \pm 20$ beats/min, $p<0.05$ ). In animals treated with propylene glycol or BQ-788, heart rate increased with $\mathrm{IH}$ by $15 \%$ and $5 \%$, respectively, although in both cases, the increase in heart rate was not statistically significant.

\section{ET-1 Levels}

The basal ET-1 level in mice under control exposure and receiving saline was $1.5 \pm 0.29 \mathrm{pg} / \mathrm{mL}$. Surprisingly, exposure to $\mathrm{IH}$ had no effect on plasma ET-1 levels in saline-treated mice (Table 1). Similarly, there was no significant difference in basal ET-1 levels in mice under control exposures receiving propylene glycol, nor were ET-1 levels changed by IH in propylene glycol-treated mice. Under control exposures, treatment with BQ-123 increased ET-1 levels by $30 \%$, although this increase did not quite reach statistical significance $(p=0.09)$. In contrast, administration of BQ-788 had the opposite effect and diminished ET-1 levels by $14 \%(p<0.05)$ in mice under control exposures. With exposure to IH, ET-1 plasma levels increased in mice receiving BQ-788 by $30 \%(p<0.05)$, but were not significantly altered in IH mice that received $B Q-123$.

\section{Glucose Tolerance}

In vehicle-treated animals, a 2-week exposure to IH elevated fasting glycemia by $29 \%$ (saline) and 18\% (propylene-glycol) and impaired glucose tolerance as assessed by GTT (Figure 1) and area

TABLE 1 | Biochemical and physiological variables in all treatment groups.

\begin{tabular}{|c|c|c|c|c|c|c|c|c|}
\hline & \multicolumn{2}{|c|}{ Saline } & \multicolumn{2}{|c|}{ BQ123 } & \multicolumn{2}{|c|}{ Propylene glycol } & \multicolumn{2}{|c|}{ BQ788 } \\
\hline & Control & IH & Control & IH & Control & IH & Control & IH \\
\hline $\mathrm{BP}_{\text {systolic }}(\mathrm{mmHg})$ & $149 \pm 8$ & $185 \pm 6^{\star}$ & $155 \pm 6$ & $148 \pm 8$ & $152 \pm 4$ & $145 \pm 5$ & $134 \pm 4$ & $147 \pm 4$ \\
\hline $\mathrm{BP}_{\text {diastolic }}(\mathrm{mmHg})$ & $123 \pm 7$ & $151 \pm 5^{\star}$ & $122 \pm 6$ & $108 \pm 6$ & $113 \pm 2$ & $115 \pm 7$ & $96 \pm 3$ & $110 \pm 5$ \\
\hline Heart rate (bpm) & $557 \pm 6$ & $654 \pm 77$ & $599 \pm 21$ & $682 \pm 20$ & $631 \pm 46$ & $724 \pm 37$ & $701 \pm 44$ & $735 \pm 23$ \\
\hline Glucose (mg/dL) & $122 \pm 7$ & $157 \pm 8^{\star}$ & $138 \pm 10$ & $171 \pm 8^{*}$ & $118 \pm 6$ & $139 \pm 8^{*}$ & $119 \pm 8$ & $137 \pm 6^{*}$ \\
\hline Insulin (ng/mL) & $0.15 \pm 0.03$ & $0.21 \pm 0.05$ & $0.33 \pm 0.07^{\ddagger}$ & $0.26 \pm 0.04$ & $0.17 \pm 0.08$ & $0.20 \pm 0.02$ & $0.27 \pm 0.06^{\ddagger}$ & $0.14 \pm 0.01^{*, \neq}$ \\
\hline ET-1 (pg/mL) & $1.50 \pm 0.29$ & $1.5 \pm 0.21$ & $2.0 \pm 0.32$ & $1.81 \pm 0.21$ & $1.23 \pm 0.11$ & $1.35 \pm 0.16$ & $1.06 \pm 0.07^{\ddagger}$ & $1.38 \pm 0.15^{\star}$ \\
\hline HOMA- $\beta$ & $18.9 \pm 2.6$ & $16.3 \pm 3.9$ & $32.2 \pm 8.1^{\ddagger}$ & $26.7 \pm 3.0^{\ddagger}$ & $23.2 \pm 9.3$ & $11.2 \pm 2.9^{*}$ & $24.0 \pm 5.0$ & $12.4 \pm 1.5^{\star}$ \\
\hline Peak insulin (ng/mL) & $0.21 \pm 0.01$ & $0.37 \pm 0.06^{\star}$ & $0.65 \pm 0.15^{\ddagger}$ & $0.31 \pm 0.02$ & $0.24 \pm 0.12$ & $0.28 \pm 0.02$ & $0.4 \pm 0.14$ & $0.27 \pm 0.03$ \\
\hline HOMA- $\beta$ peak & $13.7 \pm 1.4$ & $12.9 \pm 2.0$ & $42.2 \pm 9.6^{\ddagger}$ & $13.2 \pm 1.6^{\star}$ & $19.0 \pm 9.0$ & $16.3 \pm 2.0$ & $25.5 \pm 9.0$ & $17.4 \pm 1.7$ \\
\hline Body weight (g) & $24.0 \pm 0.4$ & $25.3 \pm 0.4$ & $23.9 \pm 0.3$ & $25.2 \pm 0.3$ & $24.6 \pm 0.3$ & $24.8 \pm 0.3$ & $24.8 \pm 0.3$ & $24.5 \pm 0.3$ \\
\hline
\end{tabular}

${ }^{*} p<0.05$ when compared to a control condition (t-test).

${ }^{\ddagger} p<0.05$ when compared to vehicle treatment (t-test). 


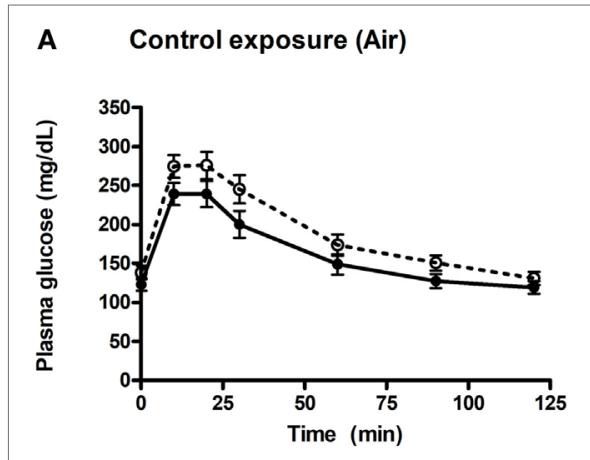

D
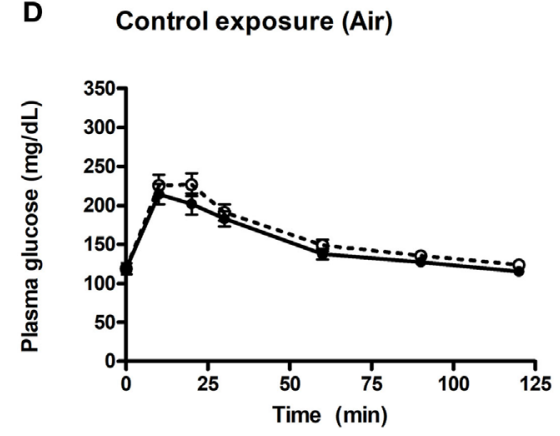

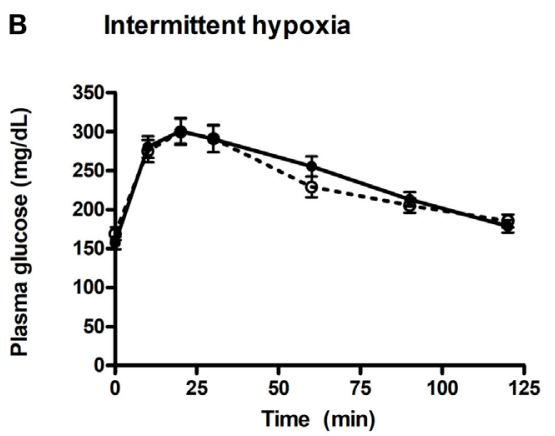

E

Intermittent hypoxia

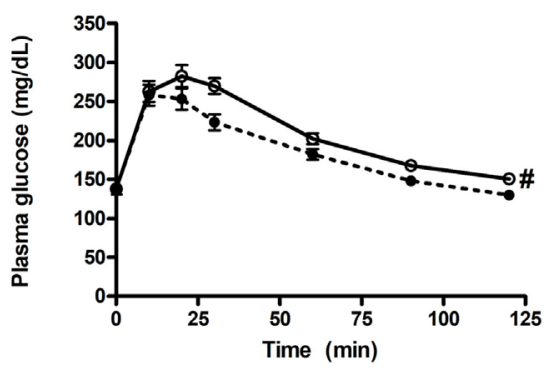

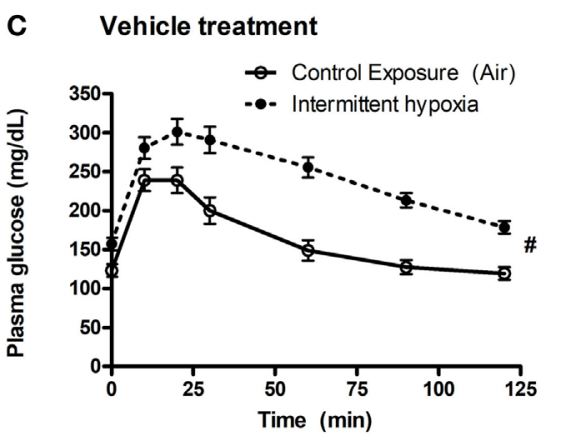

F Vehicle treatment

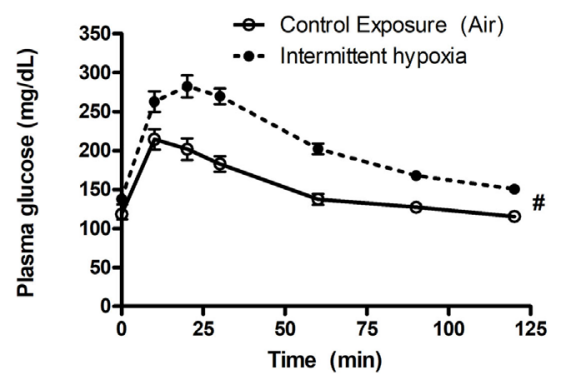

FIGURE 1 | Intraperitoneal glucose tolerance tests (GTS) in BQ-123 (A,B), BQ-788 (D,E) and vehicle (C,F) treated groups. Data were analyzed using repeated measures ANOVA analysis of the GTT profiles investigating interaction between exposure groups (drug-treated versus vehicle-treated) and time of GTT. Upper panels: BQ-123 and saline treated groups. Lower panels: BQ-788 and propylethylene glycol (vehicle). \# indicates $p<0.05$ for differences between drug-treated and vehicle-treated groups. $N=10$ for each group.

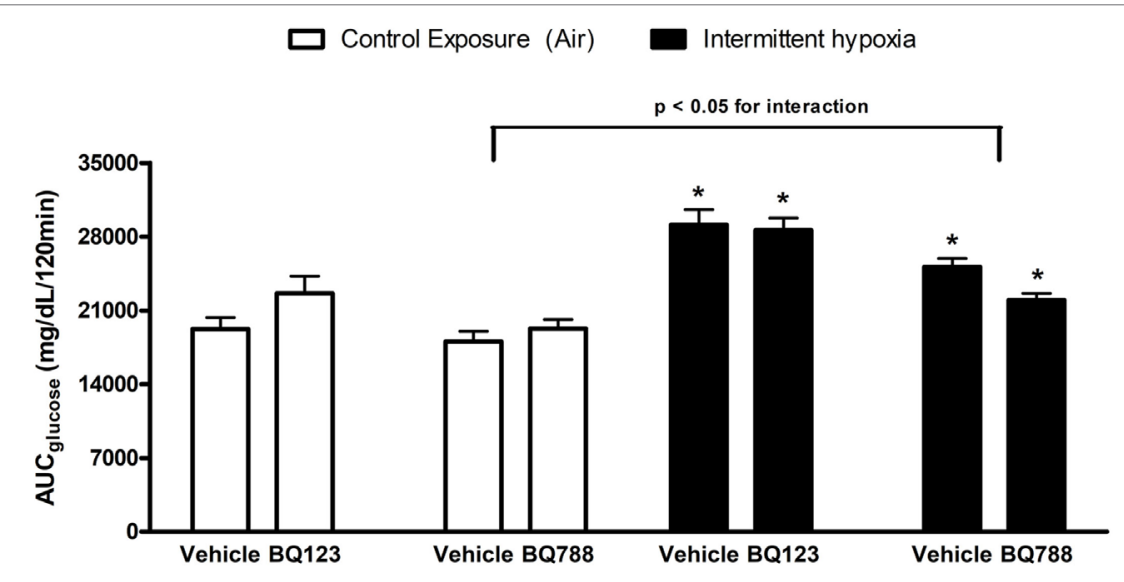

FIGURE 2 | Area under glucose curve (AUC) during intraperitoneal glucose tolerance test. Interaction between hypoxic exposure and drug treatment was investigated using two-way ANOVA. * indicates $p<0.05$ for differences between a control group (intermittent air) and a group exposed to intermittent hypoxia (IH). $N=10$ for each group.

under the glucose curve (AUC glucose; Figure 2). Neither BQ-123 nor BQ-788 altered fasting glycemia under control exposures and neither prevented the IH-induced increase in fasting glycemia (Table 1). Importantly, in animals exposed to $\mathrm{IH}$, only treatment with BQ-788 significantly improved glucose tolerance, limiting worsening of glucose tolerance with IH to $12 \%$, compared to a $28 \%$ change in vehicle-treated mice (Figures 1A,B) or a $21 \%$ change in mice treated with BQ-123 (Figures 1C,D). There was also a significant interaction between treatment with BQ-788 (versus vehicle) and exposure to IH (ANOVA, $p<0.05$ for interaction).

\section{Insulin Levels and $\beta$-Cell Function}

In saline-treated animals, with exposure to $\mathrm{IH}$ there was a trend for higher fasting blood insulin levels, although 
the change did not reach statistical significance $(p=0.34$; Table 1). In animals under control exposures, propylene glycol had no effect on fasting insulin, whereas both ET-1 receptor antagonists increased fasting insulin levels, by $113 \%$ for BQ-123 and by $56 \%$ for BQ-788 (both $p<0.05$ ). In propylene glycol-treated mice exposed to $\mathrm{IH}$, fasting insulin levels were also slightly higher, but the difference did not reach statistical significance $(p=0.82)$. In both BQ-123- and BQ-788-treated mice exposed to $\mathrm{IH}$, insulin levels were reduced compared to control exposures, although this reduction was only statistically significant for mice treated with BQ-788. However, no interaction was observed between exposure to IH and ET-1 receptor antagonist treatments, suggesting that neither BQ-123 nor BQ-788 modified the effects of IH on fasting insulin (ANOVA, $p>0.05$ ).

Assessment of the HOMA- $\beta$ index revealed that in salinetreated mice, exposure to $\mathrm{IH}$ had no effect on pancreatic $\beta$-cell function (Table 1). In mice receiving propylene glycol, the HOMA- $\beta$ index under control exposure was not different from saline-treated mice; however, the HOMA- $\beta$ index significantly decreased with IH. Treatment with BQ-123 improved insulin secretion under control exposure and IH conditions (both $p<0.05$ ). In contrast, BQ-788 had no significant effect on HOMA- $\beta$ index under control exposures, but the HOMA- $\beta$ index was reduced in mice receiving BQ-788 during IH. No interaction was observed between exposure to $\mathrm{IH}$ and ET-1 receptor antagonist treatments, suggesting that neither BQ-123 nor BQ-788 modified the effects of IH on $\beta$-cell function.

\section{Insulin Sensitivity and Body Weight Trajectory}

Analysis of individual glucose profiles and $\mathrm{AUC}_{\text {glucose }}$ revealed that exposure to $\mathrm{IH}$ worsened insulin sensitivity across all groups (Figures 3 and 4). While propylene glycol had no significant effect on insulin sensitivity, treatment with either BQ-123 (Figures 3A,B) or BQ-788 (Figures 3C,D) improved insulin sensitivity under control conditions ( $p<0.05$; Figure 4). Only BQ-788 administration also improved insulin sensitivity under IH conditions $(p<0.05)$. As a result, insulin sensitivity of mice exposed to IH while treated with BQ-788 was nearly identical to insulin sensitivity of vehicle-treated mice under control exposures $(p=0.76)$. Exposure to IH induced initial weight loss $(\sim 3-5 \%, p<0.05)$; however, there were no differences between control exposures and IH groups due to pair-feeding. Body weight trajectories of all exposure groups during the experiment are shown in Figure 5.

\section{DISCUSSION}

In the present study, we investigated whether pharmacological inhibition of ET-1 signaling with the selective $\mathrm{ET}_{\mathrm{A}}$ or $\mathrm{ET}_{\mathrm{B}}$ receptor antagonists, BQ-123 or BQ-788, respectively, would

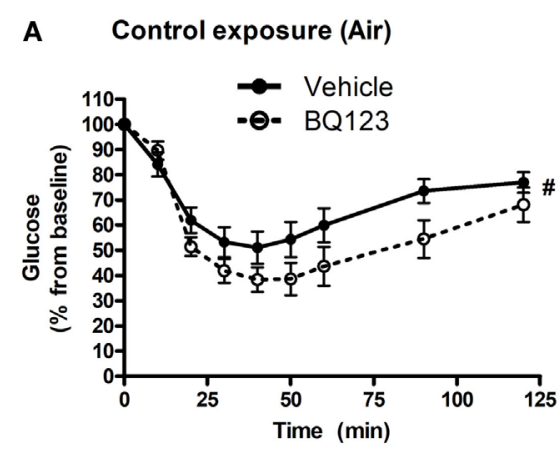

D

\section{Control exposure (Air)}

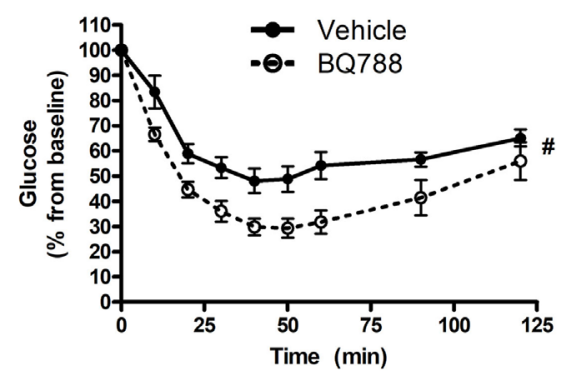

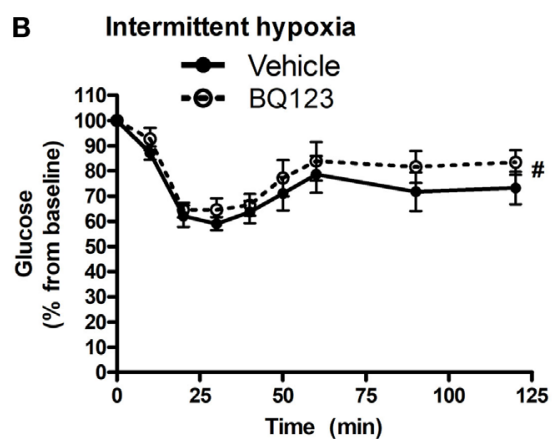

$\mathbf{E}$

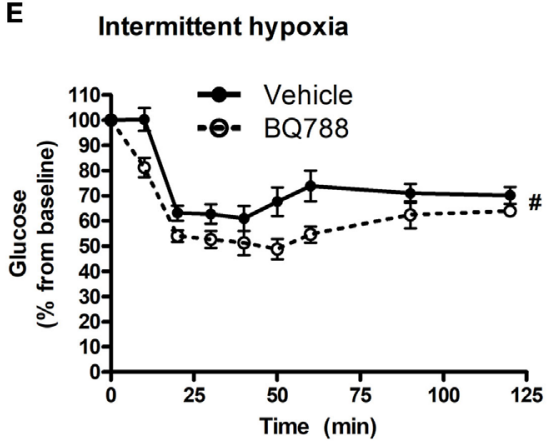

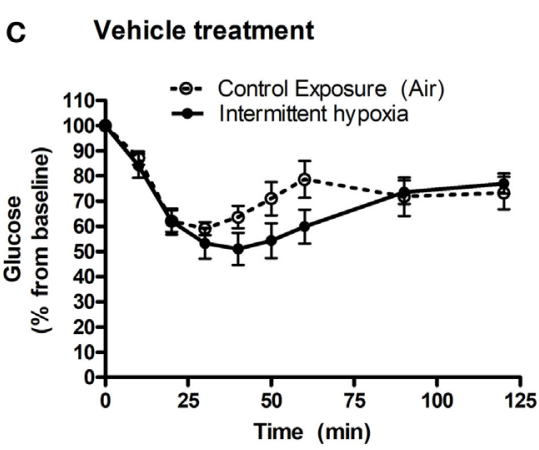

$\mathbf{F}$

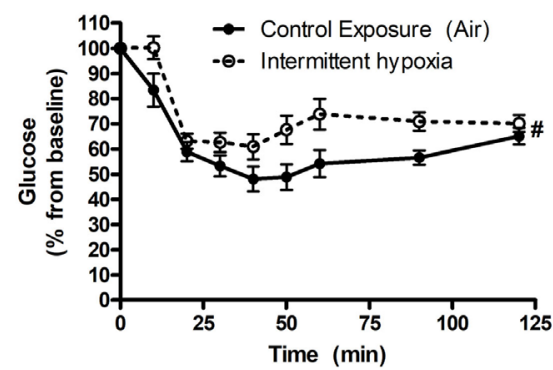

FIGURE 3 | Intraperitoneal insulin tolerance tests (ITS) in BQ-123 (A,B) and BQ-788 (D,E) and vehicle (C,F) treated groups. Data were analyzed using repeated measures ANOVA analysis of the glucose tolerance test (GTT) profiles investigating interaction between exposure groups (drug-treated versus vehicle-treated) and time of GTT. Upper panels: BQ-123- and saline (vehicle)-treated groups. Lower panels: BQ-788- and propylene glycol (vehicle)-treated groups \# indicates $p<0.05$ for differences between drug-treated versus vehicle-treated groups. $N=10$ for each group. 


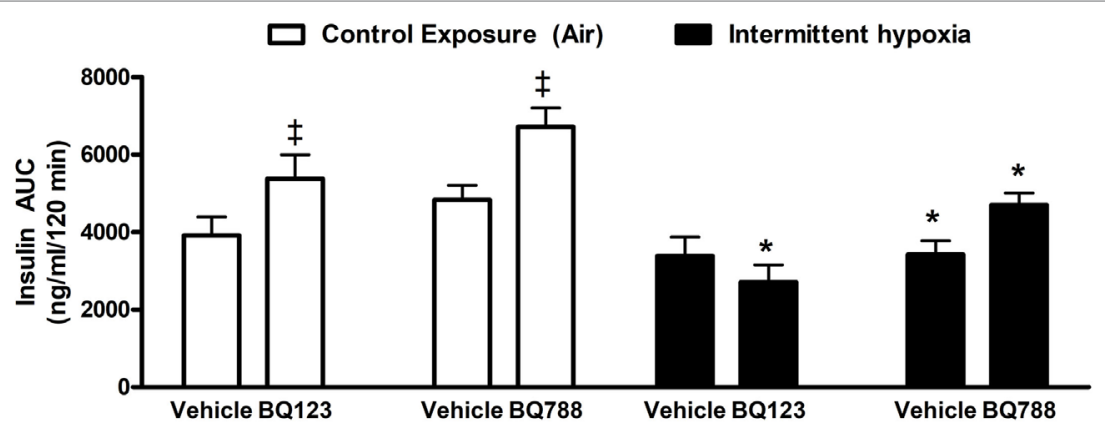

FIGURE 4 | Area under glucose curve (AUC) during intraperitoneal insulin tolerance test. Interaction between hypoxic exposure and drug treatment was investigated using two-way ANOVA. * indicates $p<0.05$ for differences between a control group (intermittent air) and a group exposed to intermittent hypoxia. ${ }^{\ddagger}$ indicates $p<0.05$ for differences between a drug-treated versus vehicle-treated groups. $N=10$ for each group.

\section{Body Weight Trajectories During Exposures}
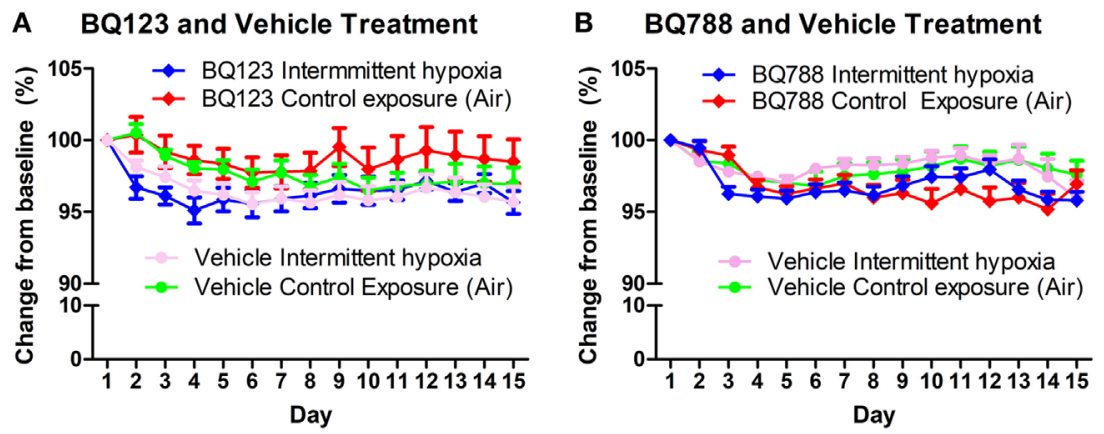

FIGURE 5 | Body weight trajectories of vehicle and BQ-123 (A) and BQ-788 (B) treated groups during control exposures and intermittent hypoxia exposure. There were no differences in body weight trajectories between groups (two-way ANOVA). $N=15$ for each group.

ameliorate the detrimental impact of IH on glucose homeostasis. We showed that treatment with BQ-788, but not BQ-123, diminished $\mathrm{IH}$-induced glucose intolerance. Additionally, both antagonists improved insulin sensitivity under control conditions; however, only BQ-788 remained effective during IH. These results suggest that ET-1 signaling via the $\mathrm{ET}_{\mathrm{B}}$ receptor contributes to $\mathrm{IH}$-induced disturbances in glucose homeostasis.

In the current study, exposure to IH elevated fasting glycemia, impaired glucose tolerance and induced IR. These findings are consistent with previous results from our lab and others using acute and prolonged $\mathrm{IH}$ exposure in obese and non-obese animals $(15-17,19,21,55,56)$. Targeting ET-1 signaling as a therapy for metabolic impairments associated with OSA was motivated by numerous studies demonstrating elevated ET-1 plasma levels in humans or animals with type 2 diabetes $(34-37,57)$, as well as by reports suggesting direct involvement of ET-1 signaling in the pathogenesis of glucose intolerance and hyperglycemia (18, $38,40-49)$. Our study was also motivated by reports of elevated ET-1 plasma levels in patients with OSA (25-27, 29-31). Similar to other groups $(58,59)$, we employed continuous subcutaneous administration of selective receptor antagonists to inhibit ET-1 signaling. Treatment with $\mathrm{ET}_{\mathrm{A}}$ receptor antagonists under control conditions slightly increased fasting glucose and insulin levels as well as worsened glucose tolerance, although none of these changes reached statistical significance. We attribute these observations to IR-inducing effects of ET-1, as plasma ET-1 levels increased by $33 \%$ after BQ-123 treatment. Surprisingly, $\mathrm{ET}_{\mathrm{A}}$ receptor antagonist treatment provided no beneficial metabolic effects under exposure to IH.

The insulin-sensitizing effects of BQ-123 as well as BQ-788 under control exposures suggest that ET-1 is involved in the regulation of whole-body IR, exerting an overall IR-promoting effect, which is alleviated after $\mathrm{ET}_{\mathrm{A}}$ or $\mathrm{ET}_{\mathrm{B}}$ receptor blockade, congruent with a previous study (42). Although speculative, we suggest that improvements in insulin sensitivity after $\mathrm{ET}_{\mathrm{B}}$ blockage are driven by the effects on adipose tissue where ET-1 induces IR via $\mathrm{ET}_{\mathrm{B}}$ receptors (60), while the beneficial effect of $\mathrm{ET}_{\mathrm{A}}$ blockade might be mediated by $\mathrm{ET}_{\mathrm{A}}$ receptors via the reduced vasoconstrictor tone and enhanced microvascular capillary bed recruitment after insulin injection and thus faster glucose removal from circulation $(61,62)$. In contrast, treatment with ET-1 receptor antagonists had no effect on fasting glucose levels neither under control exposures nor in response to IH exposure, suggesting that ET-1 is probably not a major determinant of hepatic glucose output in vivo as also supported by studies showing no effect of bosentan, a non-selective $\mathrm{ET}_{\mathrm{A}} /$ 
$\mathrm{ET}_{\mathrm{B}}$ receptor antagonist, on fasting glucose levels in diabetic rats (61) and by the fact that expression of ET-1 receptors was not detected in rat hepatocytes (63).

Interestingly, only $\mathrm{ET}_{\mathrm{B}}$ receptor antagonists improved insulin sensitivity during $\mathrm{IH}$ exposure and ameliorated the $\mathrm{IH}$-induced impairment in glucose tolerance, suggesting that $\mathrm{ET}_{\mathrm{B}}$ receptor activation and signaling might be a causal factor in driving development of adverse metabolic impairments associated with $\mathrm{IH}$ exposure. As a previous study demonstrated that $\mathrm{ET}_{\mathrm{B}}$, but not $\mathrm{ET}_{\mathrm{A}}$, receptor signaling induced $\mathrm{IR}$ in visceral human adipocytes (60), we speculate that IR is induced by intermittent hypoxic exposure particularly in adipose tissue via enhanced $\mathrm{ET}_{\mathrm{B}}$ receptor expression or augmentation of intracellular signaling. Importantly, adipose tissue IR can be induced by intermittent as well as sustained hypoxic exposure (64-66). Treatment with $\mathrm{ET}_{\mathrm{B}}$ receptor antagonist targets this dysregulation and leads to improved insulin sensitivity and, subsequently, to lower plasma glucoselevels in intraperitoneal GTT as we observed. Additionally, enhanced muscle glucose uptake and increased insulin sensitivity was reported in healthy volunteers, insulin resistant subjects and in vitro models after $\mathrm{ET}_{\mathrm{B}}$ receptor blockade $(40,47,50)$. Besides direct effects on insulin signaling/sensitivity, muscle glucose uptake can also be increased by an increase in nutritive capillary bed blood flow $(61,62)$. As higher ET-1 levels mediate $\mathrm{ET}_{B}$ receptor-dependent vasoconstriction $(67,68)$, it is plausible that $\mathrm{ET}_{\mathrm{B}}$ receptor blockade leads to vasodilation at least in some vascular beds (69) and might thus contribute to enhanced glucose uptake from circulation. The focus on IR as a major target of BQ-788 effects is further supported by the fact that parameters of $\beta$-cell function remained unaffected by $\mathrm{ET}_{\mathrm{B}}$ receptor antagonist. Further studies are needed to better elucidate opposite metabolic effects of $\mathrm{ET}_{\mathrm{A}}$ and $\mathrm{ET}_{\mathrm{B}}$ receptor signaling in metabolically relevant tissues in the context of glucose homeostasis $(49,60)$.

In contrast to $\mathrm{ET}_{\mathrm{B}}$ receptor blockade, administration of an $\mathrm{ET}_{\mathrm{A}}$ receptor antagonist had no impact on $\mathrm{IH}$-induced alterations in glucose homeostasis probably due to elevation of plasma ET-1 levels after BQ-123 administration observed in our study and reported also by others (51,70-74). Additionally, elevated glucose levels (e.g., during a postprandial state) can increase ET-1 production (75-77). It is thus plausible to hypothesize that elevated ET-1 levels in BQ-123 treated mice augmented signaling through unblocked $\mathrm{ET}_{\mathrm{B}}$ receptors with adverse metabolic outcomes. Finally, the lack of BQ-123 metabolic effect might be caused by insufficient dosing; however, this explanation seems less likely as the development of arterial hypertension typically associated with IH exposure (58) was prevented by BQ-123 administration in our study.

In the present study, we were unable to detect a significant elevation of plasma ET-1 with intermittent hypoxic exposure which is in contrast to reports documenting that exposure to sustained hypoxia or IH acutely increased plasma ET-1 levels $(32,78-80)$. However, it was also demonstrated that despite continued exposure to hypoxia, plasma ET-1 levels gradually fall and eventually return to pre-exposure levels in 14 days (80). It is also possible that the clearance of ET-1 from circulation was increased possibly through the increase in the number of endothelial $\mathrm{ET}_{\mathrm{B}}$ receptors. Finally, it is important to note that plasma ET-1 levels are subjected to rapid clearance, particularly in lungs, and thus do not necessarily reflect tissue ET-1 concentrations.

The current study has several important limitations that merit discussion. First, the duration of exposure and antagonist treatment was limited to 2 weeks due to the limited size/volume of implantable osmotic minipumps. While we and other groups have shown that a 2 -week exposure is sufficient to induce a diabetic phenotype in mice $(17,19,81)$, longer exposures and extension of this work to obese and/or older animals will provide important knowledge on metabolic consequences of chronic IH exposure under conditions more closely mimicking those observed in OSA patients. Second, GTT and ITT provide important information regarding whole-body glucose and insulin sensitivity, but more specific investigations will be necessary to separate the effects of $\mathrm{IH}$ and antagonist treatment on specific tissue processes such as insulin secretion, glucose uptake in muscle or hepatic glucose output. Third, it is important to note that several metabolically related parameters, e.g., adiposity, spontaneous food intake and physical activity were not measured in this study leaving the impact of intermittent hypoxic exposure and drug treatment on these variables unknown. It should be noted that exposure to IH induces weight loss (64), which led authors of this study as well as other investigators to weight-match control and IH groups throughout the exposures by monitoring food available to both groups to prevent differences in body weight trajectories. These differences, together with variations in duration, severity and type of hypoxic exposures (sustained versus intermittent), need to be considered in interpretation of the metabolic outcomes between studies. Finally, we used C57BL6/J mice that are susceptible to the development of diabetes due to a mutation in the nicotinamide nucleotide transhydrogenase gene (82). Future research will be required to determine whether the results obtained in this model using $\mathrm{ET}_{\mathrm{B}}$ receptor antagonism translate into management of type 2 diabetes in OSA patients.

In conclusion, we found that administration of BQ-788 reduced the metabolic toll of IH exposure in mice, improving insulin sensitivity and limiting the development of glucose intolerance. These results suggest that the adverse metabolic consequences observed under IH are at least partially mediated by ET-1 acting specifically through its $\mathrm{ET}_{\mathrm{B}}$ receptor, possibly via an effect on muscle insulin sensitivity. While it is clear that these initial studies are just a beginning, our work provides a possible rationale for exploring the potential of $\mathrm{ET}_{\mathrm{B}}$ receptor antagonism as a pharmacological treatment of metabolic abnormalities associated with OSA.

\section{ETHICS STATEMENT}

All procedures involving animals were approved by the Johns Hopkins University Animal Care and Use Committee and followed NIH principles of laboratory animal care.

\section{AUTHOR CONTRIBUTIONS}

JP participated in study design, conducted experiments, performed biochemical analysis, analyzed data and prepared a manuscript. LS and NP developed study design, supervised experiments, 
conducted experiments and participated in manuscript preparation.

\section{ACKNOWLEDGMENTS}

Part of this paper was previously presented at the American Thoracic Society International Conference and, consequently, an abstract covering less than $50 \%$ of the work presented in this paper was previously published (83).

\section{FUNDING}

This work was supported by the American Academy of Sleep Medicine Strategic Research Award 2011, NIH grants

\section{REFERENCES}

1. Punjabi NM. The epidemiology of adult obstructive sleep apnea. Proc Am Thorac Soc (2008) 5:136-43. doi:10.1513/pats.200709-155MG

2. Young T, Shahar E, Nieto FJ, Redline S, Newman AB, Gottlieb DJ, et al. Predictors of sleep-disordered breathing in community-dwelling adults: the sleep heart health study. Arch Intern Med (2002) 162:893-900. doi:10.1001/ archinte.162.8.893

3. Cano-Pumarega I, Duran-Cantolla J, Aizpuru F, Miranda-Serrano E, Rubio R, Martinez-Null C, et al. Obstructive sleep apnea and systemic hypertension: longitudinal study in the general population: the Vitoria sleep cohort 2. Am J Respir Crit Care Med (2011) 184:1299-304. doi:10.1164/rccm.201101-0130OC

4. Marin JM, Agusti A, Villar I, Forner M, Nieto D, Carrizo SJ, et al. Association between treated and untreated obstructive sleep apnea and risk of hypertension 1. JAMA (2012) 307(20):2169-76. doi:10.1001/jama.2012.3418

5. Gottlieb DJ, Yenokyan G, Newman AB, O'Connor GT, Punjabi NM, Quan SF, et al. Prospective study of obstructive sleep apnea and incident coronary heart disease and heart failure: the sleep heart health study 2. Circulation (2010) 122:352-60. doi:10.1161/CIRCULATIONAHA.109.901801

6. Redline S, Yenokyan G, Gottlieb DJ, Shahar E, O'Connor GT, Resnick HE, et al. Obstructive sleep apnea-hypopnea and incident stroke: the sleep heart health study. Am J Respir Crit Care Med (2010) 182:269-77. doi:10.1164/ rccm.200911-1746OC

7. Yaggi HK, Concato J, Kernan WN, Lichtman JH, Brass LM, Mohsenin V. Obstructive sleep apnea as a risk factor for stroke and death $1 . N$ Engl JMed (2005) 353:2034-41. doi:10.1056/NEJMoa043104

8. Yeboah J, Redline S, Johnson C, Tracy R, Ouyang P, Blumenthal RS, et al. Association between sleep apnea, snoring, incident cardiovascular events and all-cause mortality in an adult population: MESA 1. Atherosclerosis (2011) 219(2):963-8. doi:10.1016/j.atherosclerosis.2011.08.021

9. Young T, Finn L, Peppard PE, Szklo-Coxe M, Austin D, Nieto FJ, et al. Sleep disordered breathing and mortality: eighteen-year follow-up of the Wisconsin sleep cohort. Sleep (2008) 31:1071-8. doi:10.5665/sleep/31.8.1071

10. Punjabi NM, Caffo BS, Goodwin JL, Gottlieb DJ, Newman AB, O'Connor GT, et al. Sleep-disordered breathing and mortality: a prospective cohort study 2. PLoS Med (2009) 6:e1000132. doi:10.1371/journal.pmed.1000132

11. Marshall NS, Wong KK, Liu PY, Cullen SR, Knuiman MW, Grunstein RR. Sleep apnea as an independent risk factor for all-cause mortality: the Busselton health study. Sleep (2008) 31:1079-85. doi:10.5665/sleep/31.8.1079

12. Punjabi NM, Shahar E, Redline S, Gottlieb DJ, Givelber R, Resnick HE. Sleep heart health study investigators. Am J Epidemiol (2004) 160:521-30. doi:10.1093/aje/kwh261

13. Punjabi NM, Sorkin JD, Katzel LI, Goldberg AP, Schwartz AR, Smith PL. Sleepdisordered breathing and insulin resistance in middle-aged and overweight men 1. Am J Respir Crit Care Med (2002) 165:677-82. doi:10.1164/ajrccm.165.5. 2104087

14. Reichmuth KJ, Austin D, Skatrud JB, Young T. Association of sleep apnea and type II diabetes: a population-based study. Am J Respir Crit Care Med (2005) 172(12):1590-5. doi:10.1164/rccm.200504-637OC

15. Carreras A, Kayali F, Zhang J, Hirotsu C, Wang Y, Gozal D. Metabolic effects of intermittent hypoxia in mice: steady versus high-frequency applied hypoxia
HL070578 and HL099952 and by the Charles University grant PROGRES Q36.

\section{SUPPLEMENTARY MATERIAL}

The Supplementary Material for this article can be found online at https://www.frontiersin.org/articles/10.3389/fendo.2018.00280/ full\#supplementary-material.

FIGURE S1 | Estimated food intake during exposures. The amount of food provided daily per cage and food left the next day per cage was recorded. No differences were observed between groups, however this does not represent the true food intake of individual animals (some food is lost in bedding during chowing, etc...).

daily during the rest period. Am J Physiol Regul Integr Comp Physiol (2012) 303:R700-9. doi:10.1152/ajpregu.00258.2012

16. Fenik VB, Singletary T, Branconi JL, Davies RO, Kubin L. Glucoregulatory consequences and cardiorespiratory parameters in rats exposed to chronicintermittent hypoxia: effects of the duration of exposure and losartan 2. Front Neurol (2012) 3:51. doi:10.3389/fneur.2012.00051

17. Iiyori N, Alonso LC, Li J, Sanders MH, Garcia-Ocana A, O’Doherty RM, et al. Intermittent hypoxia causes insulin resistance in lean mice independent of autonomic activity. Am J Respir Crit Care Med (2007) 175:851-7. doi:10.1164/ rccm.200610-1527OC

18. Lee EJ, Alonso LC, Stefanovski D, Strollo HC, Romano LC, Zou B, et al. Timedependent changes in glucose and insulin regulation during intermittent hypoxia and continuous hypoxia 1. Eur J Appl Physiol (2013) 113:467-78. doi:10.1007/s00421-012-2452-3

19. Polotsky VY, Li J, Punjabi NM, Rubin AE, Smith PL, Schwartz AR, et al. Intermittent hypoxia increases insulin resistance in genetically obese mice. J Physiol (2003) 552(Pt 1):253-64. doi:10.1113/jphysiol.2003.048173

20. Xu J, Long YS, Gozal D, Epstein PN. Beta-cell death and proliferation after intermittent hypoxia: role of oxidative stress. Free Radic Biol Med (2009) 46:783-90. doi:10.1016/j.freeradbiomed.2008.11.026

21. Yokoe T, Alonso LC, Romano LC, Rosa TC, O’Doherty RM, Garcia-Ocana A, et al. Intermittent hypoxia reverses the diurnal glucose rhythm and causes pancreatic beta-cell replication in mice. J Physiol (2008) 586(3):899-911. doi:10.1113/jphysiol.2007.143586

22. Louis M, Punjabi NM. Effects of acute intermittent hypoxia on glucose metabolism in awake healthy volunteers. J Appl Physiol (2009) 106:1538-44. doi:10.1152/japplphysiol.91523.2008

23. Mesarwi O, Polak J, Jun J, Polotsky VY. Sleep disorders and the development of insulin resistance and obesity. Endocrinol Metab Clin North Am (2013) 42:617-34. doi:10.1016/j.ecl.2013.05.001

24. Polak J, Beamer BA, Punjabi NM. Obstructive sleep apnea and glucose metabolism. In: Allan P, editor. Sleep Apnea: Pathogenesis, Diagnosis and Treatment. New York: Informa Healthcare. (2011). p. 300-17.

25. Anunciato IF, Lobo RR, Coelho EB, Verri Junior WA, Eckeli AL, Évora PRB, et al. Big endothelin-1 and nitric oxide in hypertensive elderly patients with and without obstructive sleep apnea-hypopnea syndrome. Arq Bras Cardiol (2013) 101(4):344-51. doi:10.5935/abc.20130179

26. Gjorup PH, Sadauskiene L, Wessels J, Nyvad O, Strunge B, Pedersen EB. Abnormally increased endothelin-1 in plasma during the night in obstructive sleep apnea: relation to blood pressure and severity of disease. Am JHypertens (2007) 20(1):44-52. doi:10.1016/j.amjhyper.2006.05.021

27. Jordan W, Reinbacher A, Cohrs S, Grunewald RW, Mayer G, Ruther E, et al. Obstructive sleep apnea: plasma endothelin-1 precursor but not endothelin-1 levels are elevated and decline with nasal continuous positive airway pressure. Peptides (2005) 26:1654-60. doi:10.1016/j.peptides.2005.02.012

28. Kanagy NL, Walker BR, Nelin LD. Role of endothelin in intermittent hypoxiainduced hypertension. Hypertension (2001) 37:511-5. doi:10.1161/01. HYP.37.2.511

29. Phillips BG, Narkiewicz K, Pesek CA, Haynes WG, Dyken ME, Somers VK. Effects of obstructive sleep apnea on endothelin-1 and blood pressure. J Hypertens (1999) 17:61-6. doi:10.1097/00004872-199917010-00010 
30. Saarelainen S, Seppala E, Laasonen K, Hasan J. Circulating endothelin-1 in obstructive sleep apnea. Endothelium (1997) 5(2):115-8. doi:10.3109/ 10623329709079869

31. Zamarrón C, Riveiro A, Gude F. Circulating levels of vascular endothelial markers in obstructive sleep apnoea syndrome. Arch Med Sci (2011) 6:1023-8. doi:10.5114/aoms.2011.26615

32. Prabhakar NR, Kumar GK. Mechanisms of sympathetic activation and blood pressure elevation by intermittent hypoxia. Respir Physiol Neurobiol (2010) 174:156-61. doi:10.1016/j.resp.2010.08.021

33. Peng Y-J, Nanduri J, Zhang X, Wang N, Raghuraman G, Seagard J, et al. Endothelin-1 mediates attenuated carotid baroreceptor activity by intermittent hypoxia. JAppl Physiol (2012) 112:187-96. doi:10.1152/ japplphysiol.00529.2011

34. Kakizawa H, Itoh M, Itoh Y, Imamura S, Ishiwata Y, Matsumoto T, et al. The relationship between glycemic control and plasma vascular endothelial growth factor and endothelin-1 concentration in diabetic patients. Metabolism (2004) 53:550-5. doi:10.1016/j.metabol.2003.12.002

35. Takahashi K, Ghatei MA, Lam HC, O’Halloran DJ, Bloom SR. Elevated plasma endothelin in patients with diabetes mellitus. Diabetologia (1990) 33:306-10. doi:10.1007/BF00403325

36. Berthiaume N, Mika AK, Zinker BA. Development of insulin resistance and endothelin-1 levels in the Zucker fatty rat. Metabolism (2003) 52:845-9. doi:10.1016/S0026-0495(03)00098-2

37. Takeda Y, Miyamori I, Yoneda T, Takeda R. Production of endothelin-1 from the mesenteric arteries of streptozotocin-induced diabetic rats. Life Sci (1991) 48:2553-6. doi:10.1016/0024-3205(91)90611-E

38. Ishibashi KI, Imamura T, Sharma PM, Huang J, Ugi S, Olefsky JM. Chronic endothelin-1 treatment leads to heterologous desensitization of insulin signaling in 3T3-L1 adipocytes. J Clin Invest (2001) 107(9):1193-202. doi:10.1172/ JCI11753

39. Lee YC, Juan CC, Fang VS, Hsu YP, Lin SH, Kwok CF, et al. Evidence that endothelin-1 (ET-1) inhibits insulin-stimulated glucose uptake in rat adipocytes mainly through ETA receptors. Metabolism (1998) 47:1468-71. doi:10.1016/ S0026-0495(98)90071-3

40. Shemyakin A, Salehzadeh F, Esteves Duque-Guimaraes D, Bohm F, Rullman E, Gustafsson T, et al. Endothelin-1 reduces glucose uptake in human skeletal muscle in vivo and in vitro 1. Diabetes (2011) 60:2061-7. doi:10.2337/ db10-1281

41. Strawbridge AB, Elmendorf JS, Mather KJ. Interactions of endothelin and insulin: expanding parameters of insulin resistance. Curr Diabetes Rev (2006) 2(3):317-27. doi:10.2174/157339906777950642

42. Wilkes JJ, Hevener A, Olefsky J. Chronic endothelin-1 treatment leads to insulin resistance in vivo. Diabetes (2003) 52(8):1904-9. doi:10.2337/ diabetes.52.8.1904

43. Serradeil-Le GC, Jouneaux C, Sanchez-Bueno A, Raufaste D, Roche B, Preaux AM, et al. Endothelin action in rat liver. J Clin Invest (1991) 87:133-8.

44. Chou YC, Perng JC, Juan CC, Jang SY, Kwok CF, Chen WL, et al. Endothelin-1 inhibits insulin-stimulated glucose uptake in isolated rat adipocytes. Biochem Biophys Res Commun (1994) 202:688-93. doi:10.1006/bbrc.1994.1985

45. Ottosson-Seeberger A, Lundberg JM, Alvestrand A, Ahlborg G. Exogenous endothelin-1 causes peripheral insulin resistance in healthy humans. Acta Physiol Scand (1997) 161(2):211-20. doi:10.1046/j.1365-201X.1997.00212.x

46. Roden M, Vierhapper H, Liener K, Waldhausl W. Endothelin-1-stimulated glucose production in vitro in the isolated perfused rat liver. Metabolism (1992) 41:290-5. doi:10.1016/0026-0495(92)90273-D

47. Shemyakin A, Salehzadeh F, Bohm F, Al-Khalili L, Gonon A, Wagner H, et al. Regulation of glucose uptake by endothelin-1 in human skeletal muscle in vivo and in vitro. J Clin Endocrinol Metab (2010) 95:2359-66. doi:10.1210/ jc.2009-1506

48. Teuscher AU, Lerch M, Shaw S, Pacini G, Ferrari P, Weidmann P. Endothelin-1 infusion inhibits plasma insulin responsiveness in normal men. J Hypertens (1998) 16:1279-84. doi:10.1097/00004872-199816090-00009

49. Eriksson AK, van Harmelen V, Stenson BM, Astrom G, Wahlen K, Laurencikiene J, et al. Endothelin-1 stimulates human adipocyte lipolysis through the ET A receptor. Int J Obes (2009) 33:67-74. doi:10.1038/ijo.2008.212

50. Ahlborg G, Shemyakin A, Bohm F, Gonon A, Pernow J. Dual endothelin receptor blockade acutely improves insulin sensitivity in obese patients with insulin resistance and coronary artery disease. Diabetes Care (2007) 30:591-6. doi:10.2337/dc06-1978
51. Balsiger B, Rickenbacher A, Boden PJ, Biecker E, Tsui J, Dashwood M, et al. Endothelin A-receptor blockade in experimental diabetes improves glucose balance and gastrointestinal function. Clin Sci (2002) 103:430S-3S. doi:10.1042/CS103S430S

52. Berthiaume N, Wessale JL, Opgenorth TJ, Zinker BA. Metabolic responses with endothelin antagonism in a model of insulin resistance. Metabolism (2005) 54:735-40. doi:10.1016/j.metabol.2004.12.019

53. Tagaito Y, Polotsky VY, Campen MJ, Wilson JA, Balbir A, Smith PL, et al. A model of sleep-disordered breathing in the C57BL/6J mouse. J Appl Physiol (2001) 91(6):2758-66. doi:10.1152/jappl.2001.91.6.2758

54. Matthews DR, Hosker JP, Rudenski AS, Naylor BA, Treacher DF, Turner RC. Homeostasis model assessment: insulin resistance and beta-cell function from fasting plasma glucose and insulin concentrations in man 1. Diabetologia (1985) 28(7):412-9. doi:10.1007/BF00280883

55. Drager LF, Li J, Reinke C, Bevans-Fonti S, Jun JC, Polotsky VY. Intermittent hypoxia exacerbates metabolic effects of diet-induced obesity. Obesity (Silver Spring) (2011) 19: 2167-74. doi:10.1038/oby.2011.240

56. O'Donnell CP. Metabolic consequences of intermittent hypoxia 1. Adv Exp Med Biol (2007) 618:41-9. doi:10.1007/978-0-387-75434-5_4

57. Seligman BG, Biolo A, Polanczyk CA, Gross JL, Clausell N. Increased plasma levels of endothelin 1 and von Willebrand factor in patients with type 2 diabetes and dyslipidemia. Diabetes Care (2000) 23:1395-400. doi:10.2337/ diacare.23.9.1395

58. Allahdadi KJ, Cherng TW, Pai H, Silva AQ, Walker BR, Nelin LD, et al. Endothelin type A receptor antagonist normalizes blood pressure in rats exposed to eucapnic intermittent hypoxia 1. Am J Physiol Hear Circ Physiol (2008) 295:H434-40. doi:10.1152/ajpheart.91477.2007

59. Lund AK, Peterson SL, Timmins GS, Walker MK. Endothelin-1-mediated increase in reactive oxygen species and NADPH Oxidase activity in hearts of aryl hydrocarbon receptor (AhR) null mice 1. Toxicol Sci (2005) 88:265-73. doi:10.1093/toxsci/kfi284

60. van Harmelen V, Eriksson A, Astrom G, Wahlen K, Naslund E, Karpe F, et al. Vascular peptide endothelin-1 links fat accumulation with alterations of visceral adipocyte lipolysis. Diabetes (2008) 57:378-86. doi:10.2337/ db07-0893

61. Said SA, mmar el SM, Suddek GM. Effect of bosentan (ETA/ETB receptor antagonist) on metabolic changes during stress and diabetes. Pharmacol Res (2005) 51:107-15. doi:10.1016/j.phrs.2004.05.009

62. Muris DMJ, Houben AJHM, Schram MT, Stehouwer CDA. Microvascular dysfunction: an emerging pathway in the pathogenesis of obesity-related insulin resistance. Rev Endocr Metab Disord (2013) 14:29-38. doi:10.1007/ s11154-012-9231-7

63. Housset C, Rockey DC, Bissell DM. Endothelin receptors in rat liver: lipocytes as a contractile target for endothelin 1. Proc Natl Acad Sci U S A (1993) 90:9266-70. doi:10.1073/pnas.90.20.9266

64. Thomas A, Belaidi E, Moulin S, Horman S, van der Zon GC, Viollet B, et al. Chronic intermittent hypoxia impairs insulin sensitivity but improves wholebody glucose tolerance by activating skeletal muscle AMPK. Diabetes (2017) 66:2942-51. doi:10.2337/db17-0186

65. Regazzetti C, Peraldi P, Gremeaux T, Najem-Lendom R, Ben-Sahra I, Cormont M, et al. Hypoxia decreases insulin signaling pathways in adipocytes. Diabetes (2009) 58(1):95-103. doi:10.2337/db08-0457

66. Yin J, Gao Z, He Q, Zhou D, Guo Z, Ye J. Role of hypoxia in obesity-induced disorders of glucose and lipid metabolism in adipose tissue. Am JPhysiol Endocrinol Metab (2009) 296:E333-42. doi:10.1152/ajpendo.90760.2008

67. Mazzuca MQ, Khalil RA. Vascular endothelin receptor type B: structure, function and dysregulation in vascular disease. Biochem Pharmacol (2012) 84:147-62. doi:10.1016/j.bcp.2012.03.020

68. Rapoport RM, Zuccarello M. Endothelin(A)-endothelin(B) receptor cross talk in endothelin-1-induced contraction of smooth muscle. J Cardiovasc Pharmacol (2012) 60:483-94. doi:10.1097/FJC.0b013e31826f32c1

69. Kellogg DL, Liu Y, Pérgola PE. Selected contribution: gender differences in the endothelin-B receptor contribution to basal cutaneous vascular tone in humans. J Appl Physiol (2001) 91:2407-11; discussion 2389-90. doi:10.1152/ jappl.2001.91.5.2407

70. Borgeson DD, Grantham JA, Williamson EE, Luchner A, Redfield MM, Opgenorth TJ, et al. Chronic oral endothelin type A receptor antagonism in experimental heart failure 1. Hypertension (1998) 31(3):766-70. doi:10.1161/01. HYP.31.3.766 
71. Burke SE, Lubbers NL, Gagne GD, Wessale JL, Dayton BD, Wegner CD, et al. Selective antagonism of the ET(A) receptor reduces neointimal hyperplasia after balloon-induced vascular injury in pigs 1. J Cardiovasc Pharmacol (1997) 30:33-41. doi:10.1097/00005344-199707000-00006

72. Potter GS, Johnson RJ, Fink GD. Role of endothelin in hypertension of experimental chronic renal failure 1. Hypertension (1997) 30:1578-84. doi:10.1161/01.HYP.30.6.1578

73. Rajagopalan S, Laursen JB, Borthayre A, Kurz S, Keiser J, Haleen S, et al. Role for endothelin-1 in angiotensin II-mediated hypertension 2. Hypertension (1997) 30:29-34. doi:10.1161/01.HYP.30.1.29

74. Verhaar MC, Grahn AY, Van Weerdt AW, Honing ML, Morrison PJ, Yang YP, et al. Pharmacokinetics and pharmacodynamic effects of ABT-627, an oral ETA selective endothelin antagonist, in humans 1. Br J Clin Pharmacol (2000) 49:562-73. doi:10.1046/j.1365-2125.2000.00171.x

75. Hargrove GM, Dufresne J, Whiteside C, Muruve DA, Wong NC. Diabetes mellitus increases endothelin-1 gene transcription in rat kidney 3. Kidney Int (2000) 58(4):1534-45. doi:10.1046/j.1523-1755.2000.00315.x

76. Manea SA, Manea A, Heltianu C. Inhibition of JAK/STAT signaling pathway prevents high-glucose-induced increase in endothelin-1 synthesis in human endothelial cells 1. Cell Tissue Res (2010) 340(1):71-9. doi:10.1007/ s00441-010-0936-1

77. Verma S, Maitland A, Weisel RD, Li SH, Fedak PW, Pomroy NC, et al. Hyperglycemia exaggerates ischemia-reperfusion-induced cardiomyocyte injury: reversal with endothelin antagonism 2. J Thorac Cardiovasc Surg (2002) 123:1120-4. doi:10.1067/mtc.2002.121973

78. Chester AH, Yacoub MH. The role of endothelin-1 in pulmonary arterial hypertension. Glob Cardiol Sci Pract (2014) 2014:62-78. doi:10.5339/gcsp. 2014.29
79. Miyagawa K, Emoto N. Current state of endothelin receptor antagonism in hypertension and pulmonary hypertension. Ther Adv Cardiovasc Dis (2014) 8:202-16. doi:10.1177/1753944714541511

80. Ni Z, Bemanian S, Kivlighn SD, Vaziri ND. Role of endothelin and nitric oxide imbalance in the pathogenesis of hypoxia-induced arterial hypertension. Kidney Int (1998) 54:188-92. doi:10.1046/j.1523-1755.1998.00987.x

81. Polak J, Shimoda LA, Drager LF, Undem C, McHugh H, Polotsky VY, et al. Intermittent hypoxia impairs glucose homeostasis in C57BL6/J mice: partial improvement with cessation of the exposure. Sleep (2013) 36:1483-90. doi:10.5665/sleep.3040

82. Toye AA, Lippiat JD, Proks P, Shimomura K, Bentley L, Hugill A, et al. A genetic and physiological study of impaired glucose homeostasis control in C57BL/6J mice. Diabetologia (2005) 48(4):675-86. doi:10.1007/s00125-005-1680-z

83. Polak J, Shimoda L, Punjabi N. Blockade of endothelin-1 receptor type B ameliorates glucose intolerance in A mouse model of sleep apnea. Am J Respir Crit Care Med (2013) 187:A2308.

Conflict of Interest Statement: The authors declare that the research was conducted in the absence of any commercial or financial relationships that could be construed as a potential conflict of interest.

Copyright (c) 2018 Polak, Punjabi and Shimoda. This is an open-access article distributed under the terms of the Creative Commons Attribution License (CC $B Y)$. The use, distribution or reproduction in other forums is permitted, provided the original author(s) and the copyright owner are credited and that the original publication in this journal is cited, in accordance with accepted academic practice. No use, distribution or reproduction is permitted which does not comply with these terms. 